\title{
Analyze Climate Change Against Occurance of Dengue Fever in SouthTangerang City In 2013-2018
}

\author{
Ernyasih \\ \{ummi.rifali@gmail.com\} \\ Universitas Muhammadiyah Jakarta, Indonesia
}

\begin{abstract}
Climate change makes mosquitoes able to adapt and survive and thrive in areas that were previously impossible to become mosquito habitat. In 2015, South Tangerang City was the City with the highest number of cases of Dengue Hemorrhagic Fever in Banten Province. The number reached 1,834 cases with 15 deaths. The purpose of this study to determine the relationship of climate change (rainfall and wind speed) to the occurrence of Dengue Hemorrhagic Fever in South Tangerang City in 2013-2018. This research is quantitative and is a type of descriptive epidemiological research with an ecological study design. This study uses secondary data for 6 years (20132018). Rainfall and wind speed have a significant relationship with the incidence of DHF in South Tangerang City in 2013-2018.

Keywords : Climate Change, Dengue Hemorrhagic Fever, South Tangerang City
\end{abstract}

\section{INTRODUCTION}

Climate change is a global challenge in the $21^{\text {st }}$ century. The severity of the effects of climate change poses a threat to all aspects of the scope that are home to humans and other living things [1]. The Indonesian state, which consists of several islands, both large and small islands, makes Indonesia the largest archipelagic country. in this world. Geographically, Indonesia has become a country that is vulnerable to the effects of climate change which are increasingly severe [2]. By definition, climate is the average weather described in terms of averages and other statistics that measure elements over a period of time and may be more than one specific geographical area [3]. The most significant climate variables to influence a disease, among others namely temperature, rainfall, humidity, and wind speed [4].

Climate change has an indirect impact on the occurrence of Dengue Hemorrhagic Fever, which causes the area infected by the disease vector to become wider and the increasing number and activity of mosquitoes infected by the Dengue virus [5]. Countries with a tropical climate are endemic areas for the spread of Dengue Hemorrhagic Fever reported as the second country with the largest case of Dengue Hemorrhagic Fever among 30 other endemic countries. During the last 10 
years since 2008 in Indonesia, the morbidity rate of Dengue Hemorrhagic Fever tends to be high until 2010, then that number has decreased in 2011 to 27.67 per 100,000 population, then in 2011 experienced the upward trend in 2016 reached 78.85 per 100,000 population[6].

Based on data in 2016, in Banten Province, the incidence rate of Dengue Fever was 68.5 per 100,000 population with a Case Fatality Rate of 1.6 percent. South Tangerang City was the city with the highest number of cases of Dengue Hemorrhagic Fever in Banten Province. . The number reached 1,834 cases with the number of deaths by 15 people [7].

The results of previous studies indicate that there is a strong relationship between humidity and rainfall on the occurrence of Dengue Hemorrhagic Fever in the period 2000-2009 and for analysis per year, the results show a strong relationship between temperature and the incidence of Dengue Fever in 2006 in East Jakarta City[8].

\section{RESEARCH METHOD}

This research is quantitative and is a type of descriptive epidemiological research with ecological study design. The research location was in the City of South Tangerang in March to July 2019. The location was chosen because South Tangerang City is one of the areas with a high dengue hemorrhagic fever event which reached 1,834 cases in 2015. The population in this study were all residents in the city Tangerang Selatan with Dengue Hemorrhagic Fever cases from 2013 to 2018. The dependent variable is the occurrence of Dengue Hemorrhagic Fever and its independent variable, climate (rainfall and wind speed). Data were analyzed with the Pearson moment test to determine the relationship between climate variables (rainfall, and wind speed) against Dengue Hemorrhagic Fever.

\section{RESULTS AND DISCUSSION}

\section{a. Univariate Analysis}

The following is an overview of the average rainfall and average monthly wind speed during 2013-2018 in Kota Tangerang Selatan 


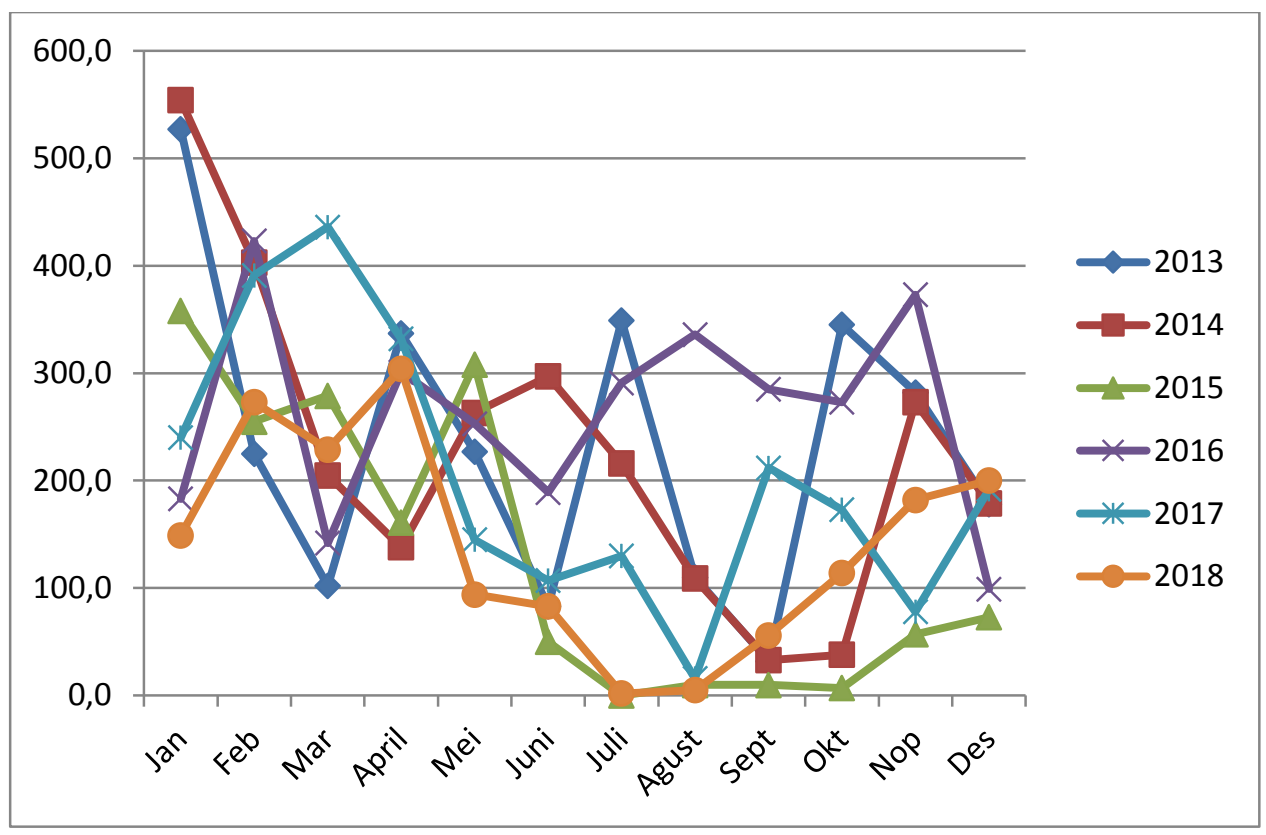

Figure 1. Overview of average rainfall per month in South Tangerang City in 2013-2018

Based on Figure 1, it is known that during 2013-2018, the highest rainfall occurred in January 2014 which amounted to $554 \mathrm{~mm}$, while the lowest rainfall occurred in July 2015 which was $0 \mathrm{~mm}$ or no rain. 


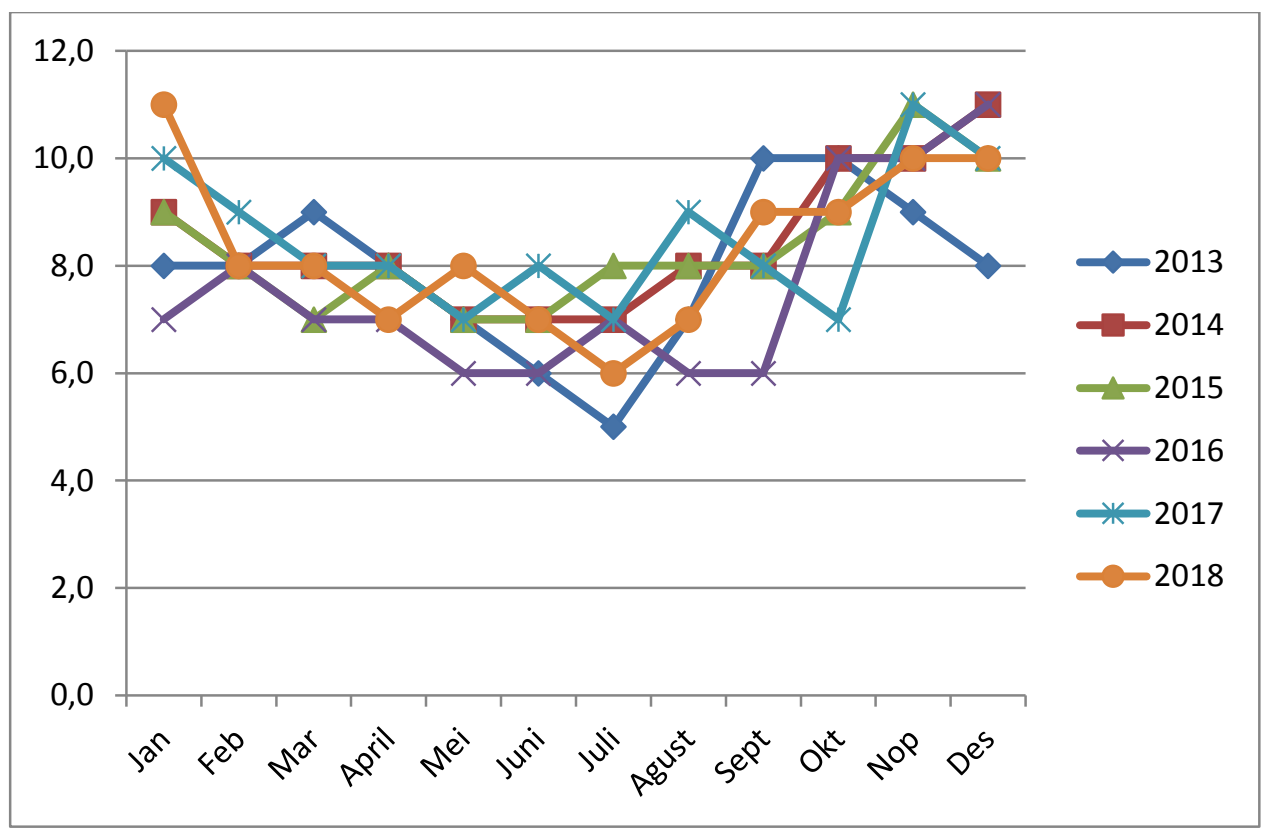

Figure 2. Overview of average monthly wind speeds in South Tangerang City in 20132018

Based on Figure 2, it is known that during 2013-2018, the highest wind speed occurred in December 2016 and January 2018 which was $11 \mathrm{~km} /$ hour, while the lowest wind speed occurred in July 2013 which was $5 \mathrm{~km} /$ hour. 


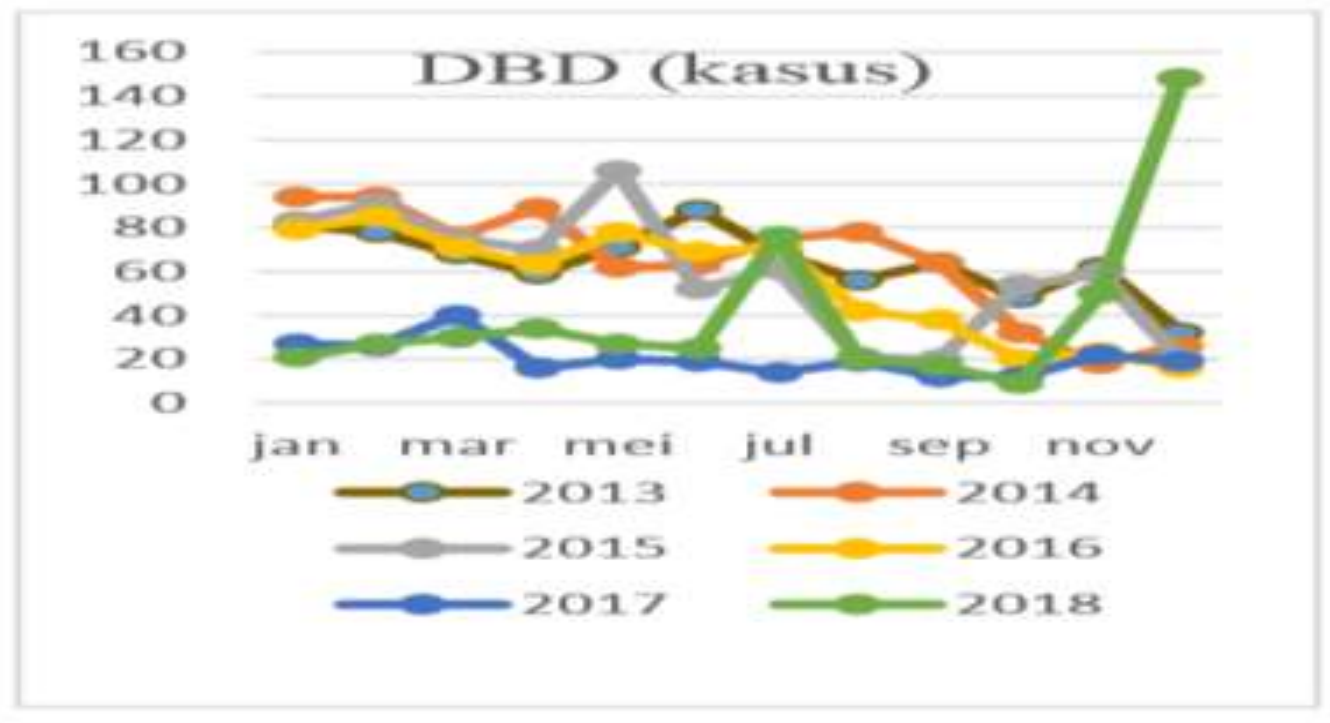

Figure 3. Overview of the incidence of dengue hemorrhagic fever per month in the city of South Tangerang

Based on Figure 3, it is known that during 2013-2018, the highest incidence of Dengue Fever occurred in December 2018 with 148 cases, while the lowest incidence of dengue occurred in October 2018, 9 cases. In the same year and only in the span of 1 month, the incidence of dengue fever can increase dramatically.

\section{b. Bivariate Analysis}

Following are the results of bivariate tests between rainfall and wind speed for the occurrence of Dengue Hemorrhagic Fever in South Tangerang City in 2013-2018.

Table 1. Pearson test results of the relationship between rainfall and wind speed on the incidence of DHF

\begin{tabular}{lll}
\hline & $\mathrm{DBD}$ & \\
\hline Variable & $\mathrm{R}$ & $\mathrm{P}$ \\
\hline Rainfall & 0.277 & 0.019 \\
\hline Wind Speed & -0.273 & 0.020 \\
\hline
\end{tabular}


Based on the table above, it is known that from 2013-2018 there was a significant relationship between rainfall and the incidence of dengue fever because the test results showed a value of $p$ $<0.05$. Correlation test results ( $\mathrm{r}$ ) of 0.277 , meaning that they have a significant relationship, weak strength with a positive direction. The wind speed variable indicates that there is a significant relationship between wind speed and the incidence of dengue fever because the test results show a $\mathrm{p}$ value $<0.05$. The correlation test results $(\mathrm{r})$ of -0.273 , meaning that they have a significant relationship, have weak strength with a negative direction.

\subsection{Relationship of rainfall to the occurrence of Dengue Hemorrhagic Fever in South Tangerang City in 2013-2018}

Bivariate test results showed that there was a significant relationship between rainfall and the incidence of dengue in South Tangerang City in 2013-2018. The results of this study are not in line with research conducted in Serang District which states that there is no significant relationship between rainfall and the incidence of dengue fever in Serang Regency 2007-2008 ( $p=0.114$ ) [9]. Other research also states that there is no significant relationship significant between rainfall on the occurrence of dengue fever in Pekanbaru City in 1999-2008 ( $\mathrm{p}=0.122)$ [10]. Rainfall and low angina velocity will add to puddles as vector breeding grounds. The effect of rainfall on vectors varies greatly, depending on the amount of rainfall, the frequency of rainy days, geographical conditions, and the physical properties of the land or habitat type [11].

Average monthly rainfall in the city of South Tangerang in 2013-2018 is $201 \mathrm{~mm}$ which means it is included in the medium monthly rainfall. This will be good for vector breeding.

\subsection{The relationship of wind speed to the occurrence of Dengue Hemorrhagic Fever in South \\ Tangerang City in 2013-2018}

Bivariate test results show that the relationship of wind speed to the incidence of dengue in South Tangerang City in 2013-2018 there is a significant relationship with the negative pattern between the wind speed of the incidence of dengue in South Tangerang City in 2013-2018, it can be concluded that a decrease in wind speed will not increase the incidence of dengue fever, and vice versa. This study is not in line with research conducted in Serang District which states that there is no meaningful relationship between climate factors, wind speed and DHF incidence rates.[9].

The Aedes aegypti mosquito has the most effective flight distance of 50-100 miles or 81-161 $\mathrm{km}$. Wind speed directly affects the ability to fly vector if the wind speed is $11-14 \mathrm{~m} / \mathrm{sec}$ it will inhibit mosquito flying activity [11]. The average wind speed in South Tangerang City in 20132018 is $7.69 \mathrm{~km} /$ hour and the figure does not meet the wind speed limit to inhibit mosquito 
activity. The wind has a significant influence on the behavior of Aedes sp. who prefer to be in a room that has a small wind speed, so the possibility will affect the spread of dengue fever [12].

\section{CONCLUSIONS}

Based on the results and discussion of the research that has been described, it can be concluded that the rainfall and wind speed variables have a significant relationship with the incidence of dengue fever in the city of South Tangerang in 2013-2018. Through this research, the government is expected to be able to adjust the health program as a precautionary measure against the incidence of DHF in accordance with climate change. For the community to always support and cooperate in implementing health programs that have been launched by the government. Other researchers are expected to examine other climate variables that are likely to influence the incidence of dengue fever and with a longer time span.

\section{REFERENCES}

[1] World Health Organization. COP 24 Special Report: Health and Climate Change. 2018

[2] Narendra, R. N. dan B. H. Study of Rainfall , Temperature and Type of Climate Change in Lombok Island Ecosystem Zone. Jurnal Analisis Kebijakan Kehutanan. 2011.

[3] Wirjohamidjoyo S, Swarinoto Y. Iklim Kawasan Indonesia (Dari Aspek Dinamik-Sinoptik). Badan Meteorologi Klimatologi dan Geofisika; 2010

[4] Paul E. Parham, Celine Christiansen-Jucht, D. P. and E. M. Understanding and Modelling the Impact of Climate Change on Infectious Disease- Progress and Future Challenges. Intech, i(tourism). 2016.

[5] Kurane, I. The Effect of Global Warming on Infectious Diseases. Osong Public Health and Research Perspectives, 1(1). 2010.

[6] Kementerian Kesehatan RI. Data dan Informasi Profil Kesehatan Indonesia.2018

[7] Profil Kesehatan Provinsi Banten. Data Profil Kesehatan Provinsi Banten. 2016.

[8] Febriasari, S. G. Perubahan Iklim Dengan Kejadian Penyakit Demam Berdarah Dengue DBD ) Di Kota Administrasi Jakarta Timur Tahun 2000-2009. 2011.

[9] Dini, A. M. V., Fitriany, R. N., \& Wulandari, R. A. Faktor Iklim dan Angka Insiden Demam Berdarah Dengue di Kabupaten Serang. MAKARA KESEHATAN. 2010.

[10] Bambang, Masrizal, \& Machmud, R. Hubungan Unsur Iklim Dengan Kejadian Penyakit Demam Berdarah Dengue Kota Pekanbaru Tahun 1999- 2008. Jurnal Kesehatan Masyarakat. 2010.

[11] Arsin, A. A. Epidemiologi Demam Berdarah Dengue ( DBD ) Di Indonesia (A. Sade, ed.). Makassar,: Masagena Press. 2013.

[12] Handayani, P. 2012. Hubungan Antara Faktor Iklim dan Kejadian Demam Berdarah Dengue (DBD) di Wilayah DKI Jakarta Tahun 2008-2011. 